\title{
Research on Urbanization in the Developing World: New Directions
}

\author{
Thomas Park, James Greenberg, Edward Nell, Stuart Marsh, Mamadou Baro, Mourad Mjahed
}

\section{Perspective on Current Results}

NSF funded a three year project (\#9817743) from 1999 to 2003 (one year no cost extension) to develop a way, using remote sensing, to create an accurate sampling framework to study large urban centers in the developing world. The project used satellite imagery from the early 1980s through 1999 to create a classification system for urban habitation in six cities (Marrakech Morocco, Dakar - Senegal, Bamako - Mali, Niamey - Niger, Dodoma - Tanzania, and Gaborone Botswana). The use of multiple images makes it possible to create urban classes such as squatter settlement present in 1982, low income housing present in 1992 but not in 1982, or villas appearing after 1992. Multiple urban classes based on date of appearance and quality of housing plus the ability, using the latest image, to sample from all residential areas and to know how much housing fits into each class makes it possible to design a sampling framework to study an important number of urban issues. The original project was primarily a methodological project designed to see if using this technology we would indeed find strong correlations between quality and date of appearance of housing and a variety of socio-economic variables and environmental concerns.

NSF also funded a project conference (\#0138217) held in Dakar, Senegal (5-10 January 2002) to which project participants from Morocco, Senegal, Mali, Niger, Tanzania and Botswana contributed papers and powerpoint presentations. In addition a delegation of five senior government figures and university scholars from Mauritania attended and presented an exceedingly well researched powerpoint presentation on Nouakchott focusing on urban growth and environmental issues that was intended to highlight the value of implemting our methodology in Mauritania. Many representatives from various administrative levels (federal and municipal) in Dakar also attended and made presentations. A number of the papers have been published (Lesetedi 2003, Lupalo 2003, Mjahed and Christopherson 2003, Park and Baro 2003, Sardier 2003) but the majority of the power point presentations of GIS results have not yet been reworked into articles.

The clear statistical evidence that the core project expectation of a tight relationship between habitation quality, location, and date of construction was not only reasonable but well supported are provided in Park and Baro (2003, this issue). This article asked first if the methodology was accurately picking out housing that had less in-class variation than between class variation (referring to the urban classes developed using satellite imagery). Then it asked if there was nevertheless value in selecting members of each class from a variety of neighborhoods and locales around the city. Using a Kruskal Wallis analysis we concluded that not only were variations in the housing variables (room size, construction material, provision of urban services, rent, number of rooms and other variables) consistently picked up by the classification system but additional variation could be captured within each class by selecting points based on location within the city fabric. Using a similar approach we also examined the degree to which the sampling framework captured homogeneity in a variety of socio-economic variables (income, expenses per capita, monthly expenses, number of persons in the household, ratio of producers to consumers, and others) within each class and across the city. In both the case of the socio-economic variables and the housing variables the probability of the null hypothesis (that the classification system does not effectively group households into homogenous units both in terms of habitation variables and socio-economic ones was extremely small (see Table 1). This paper thus provides the core analysis substantiating the value of the methodology but also supports a secondary component of the methodology which was to not rely entirely on the classification system but to combine it with location so that households in a single habitation class are drawn from the maximal spatial extent of that class in order to capture the full range of variability within the class (Marsh et al 2003, this issue).

The small modules on a variety of topics included in the six city surveys were not intended to collect definitive data, in fact they were entirely designed to test the utility of the new methodology. The PI (Park) in conjunction with two graduate students (Mjahed and Cisneros) also created an agent based model (using the modeling software REPAST) to address a question of interest to researchers in Africa: why is there such enormous variation in household size in African cities. The starting premise of this model was that there may be several viable economic strategies within the urban space of African cities and these make it reasonable to have small, intermediate 
Park, Greenberg, Nell, Marsh, Baro and Mjahed

and large (even 44 member) households. This was brought home when Park, in a series of conference papers (Park 2002, 2003, Park and Mjahed 2003) compared Marrakech, Bamako and Niamey and found that the three divisions of Niamey (Communes 1-3) exhibited radically different household sizes with one commune ressembling the norm for Marrakech (nuclear households) another resembling Bamako (tendency to large household sizes, and the remaining Commune (3) clearly being in an intermediary position.

\begin{tabular}{|c|c|c|c|c|}
\hline Table 1 & F-Statistic & $\begin{array}{l}\text { Probability } \\
\mathrm{H}_{0}\end{array}$ & $\begin{array}{l}\text { Adjusted } \\
\text { R-squared }\end{array}$ & t-Statistic \\
\hline Marrakech & 10.09 & 0.0001 & 0.0757 & \\
\hline Number of Rooms & & 0.000 & & 4.14 \\
\hline Amenities & & 0.006 & & 2.79 \\
\hline Bamako & 35.4 & 0.0000 & 0.2228 & \\
\hline Age of HH Head & & 0.000 & & 5.13 \\
\hline Years in Residence & & 0.000 & & 4.14 \\
\hline $\begin{array}{l}\text { Niamey } \\
\text { Commune } 1\end{array}$ & 28.49 & 0.000 & 0.2123 & \\
\hline Age of HH Head & & 0.000 & & 5.34 \\
\hline Niamey & 34.51 & 0.000 & 0.4438 & \\
\hline Commune 2 & & & & \\
\hline Age of HH Head & & 0.002 & & 3.23 \\
\hline Years in Residence & & 0.000 & & 5.06 \\
\hline Niamey & 7.13 & 0.0024 & 0.2393 & \\
\hline Commune 3 & & & & \\
\hline Age of HH Head & & 0.078 & & 1.81 \\
\hline Years in Residence & & 0.018 & & 2.48 \\
\hline
\end{tabular}

Source: Park, Mjahed and Cisneros 2002.

This range of applicability of a model is illustrated in the Table 1 where it is clear that a significant portion of household size can be explained by the age of the head of household and their years in residence in Bamako, generally, and to varying degrees in the various Communes of Niamey. The table is parsimonious and only shows variables that were significant. While a different model has relevance in Marrakech the relevance of the two variables, age of household head and years in residence, varies dramatically within Niamey.

Park and Mjahed (2003) developed the data further and then Park, Mjahed and Cisneros developed the relatively simple agent based model using three key variables (education, generosity, and ambition - with mathematical functions determining both costs and returns to different levels of each variable) and two options for inheritance / emulation for each household (households were grouped into kin groups and could strive to emulate the better performing kin members and were also grouped into one of five spatially defined neighborhoods and could try to emulate the better performers in their neighborhood). While the model is simple we were pleased that it did not devolve into a single strategy and instead maintained a significant level of complexity after hundreds of thousands of iterations. In order to estimate complexity we calculated entropy levels at the beginning of a run (with randomized start values) and at the end 
Research on Urbanization in the Developing World: New Directions

simply assuming five levels for each of three variables (giving a variable space of $5^{\wedge} 3$ ) and using the formula:

$$
H=\sum_{S} P_{i} \cdot \log \left(\frac{1}{P_{i}}\right)
$$

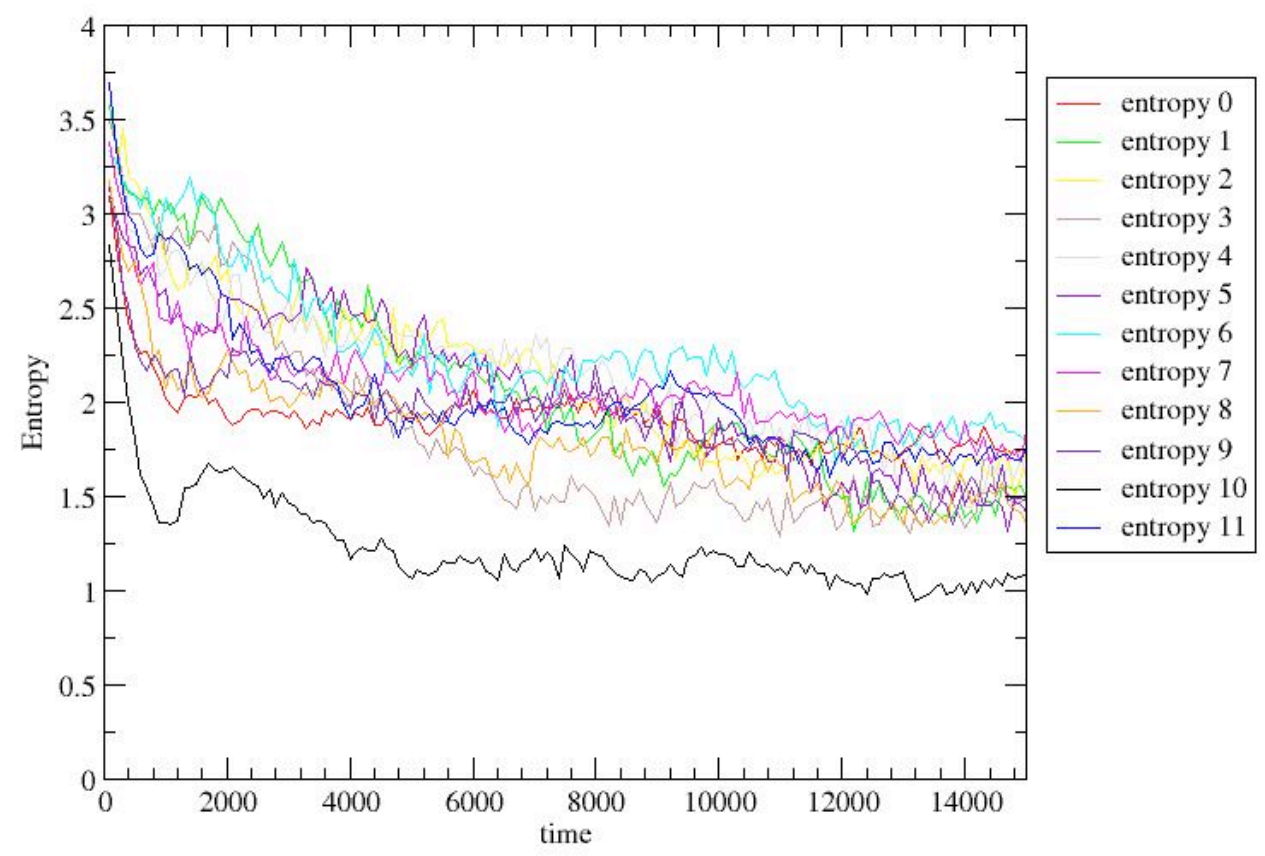

Figure 1. Measures of Entropy in Agent Based Household Model. Source Park, Mjahed, Cisneros 2002.

The series of long runs (Figure 1) illustrate the movement of the system toward relatively stable levels of complexity. Park in conjunction with Steve Lansing (PI) and two other co-PIs (Lisa Curren and Mary Stiner) received NSF funding to put on a conference (BCS-0215898 - BE/ $\mathrm{CNH}$ : Conference on Robustness of Coupled Natural and Human System, 28 May 2003) at the Santa Fe Institute. While most of the other presentations focused on natural ecosystems Park, Mjahed and Cisneros (Forthcoming) presented their urban model at the conference and a revised paper is in preparation for publication. We hope to further develop the idea that ecological models based on information theory such as that of Ulanowicz (1997) hold promise to unite social and natural complex systems within one framework and that such an approach could provide an entirely new way to study the viability of large cities.

This special issue of the Journal of Political Ecology includes revised essays originally presented at an NSF funded Conference in Dakar by (Park and Baro, Lupalo, Lesetedi, Ijagbemi, and Sardier as well as a link to the revised paper of Christopherson and Mjahed), a brief methodological paper by Marsh et al, and a book review by Park which looks in depth at the state of the art in urbanization studies via an examination of the key themes of nine major works of cities and city planning. Many other presentations were made at the conference but most were power points focusing on graphical display of data or broad policy discussions of the application 
Park, Greenberg, Nell, Marsh, Baro and Mjahed

of the methodology. We have focused in the special issue on papers which either directly explain the methodology or provide examples of how it can be complemented by other methodologies for particular purposes.

\section{Literature Review: Contextualization of the research}

The earth is rapidly urbanizing and the developing world has led the way since the 1970s yet its rapidly growing new cities have been more characterized by a massive growth in slums than by a significant development of urban infrastructure: SSA in fact appears to have a larger percent of its urban population in slums ( $71.9 \%$ vs. $31.6 \%$ worldwide) than any other region (Davis 2004, United Nations Habitat 2003). In all, 166 million of the 231 million urban dwellers in SSA live in what the UN designates a slum. This trend toward urbanization without growth (since the debt crisis of the 1970s and subsequent restructuring policies economies in most African countries were contracting by 2 to 5 percent per year) has been termed perverse urbanization as it seems to contradict accepted economic models (Davis 2004:9).

Dual economy models (Lewis 1954, Fei and Ranis 1964) were based on the idea of urban industrialization attracting rural people to cities and modeled the resulting employment impacts in each sector while more recent models (Feldman 1989) have suggested that a key short term concern is the trade-off between GNP and unemployment. Todaro's popular and sophisticated model of rural-urban migration explained the phenomenon as reflecting a comparison of expectations of urban employment with the expectation of employment in the rural area where expectation is a result of multiplying the chance of employment by the expected income (Todaro 1969, Fields 1975, 1986, Harris and Todaro 1970, Lipton 1977, Lukas 1985, Stiglitz 1976). This model was able to explain the presence of large numbers of unemployed or underemployed in the urban area on the assumption that urban incomes when found were several multiples of rural incomes and thus even a 50\% chance of employment could work out to a higher expectation for urban income. The model fundamentally proposed that "expectations" would adjust and replace pressures to equalize incomes in the rural and urban sectors and so function to stabilize rates of rural-urban migration. Recent extensions of the dual economy model focus on modern and traditional sectors within the rural and urban areas building along similar lines a dual-dual economy model (Stifel and Thorbecke 2003, Thorbecke 1997).

While the focus of much of the migration literature relying on the Harris-Todaro model is on suggesting possible policies to stimulate economic growth without exacerbating urban problems, some scholars (Bencivenga and Smith 1997) have argued that rural-urban migration and urban underemployment can create development traps including severe recessions that may be extremely difficult to escape. Benciveng and Smith suggest that a key focus should be on how policies such as agricultural subsidies or provision of urban services impact migration, urban under employment and capital formation and why these impacts are so strong in the developing world - they conjecture that the rural areas of the developed world are no longer labor intensive while the developing world still has key aspects of a dual economy.

While it is clear that SSA is rapidly urbanizing, it is not at all clear that science yet has a good handle on why developing countries are urbanizing in the way they are or at the rate they are. This can be seen fairly easily by examining the growth of cities with populations over one million.

In Figure 2, we have added a geometric curve (dashed line) to the U.N. data to demonstrate how closely the growth of cities in developing countries with over a million inhabitants has followed a geometric growth path since the 1950s. This suggests that causality having comparable impacts, in terms of its effects on net urban population growth in the developing world, has been fairly continuous for more than half a century. We might tentatively conjecture that the post Bretton Woods world economy has been fairly consistent from decade to decade not in the details of its arrangements but in its overall stimulative impacts on urban growth in the developing world while it has not had the same impacts on urban growth in the developed countries. It may be reasonable to assume that the Harris and Todaro model contributes to explaining this differential growth, but it clearly provides no deep explanation of the rate nor of the continuity of this growth. 


\section{Cities with over a million inhabitants}

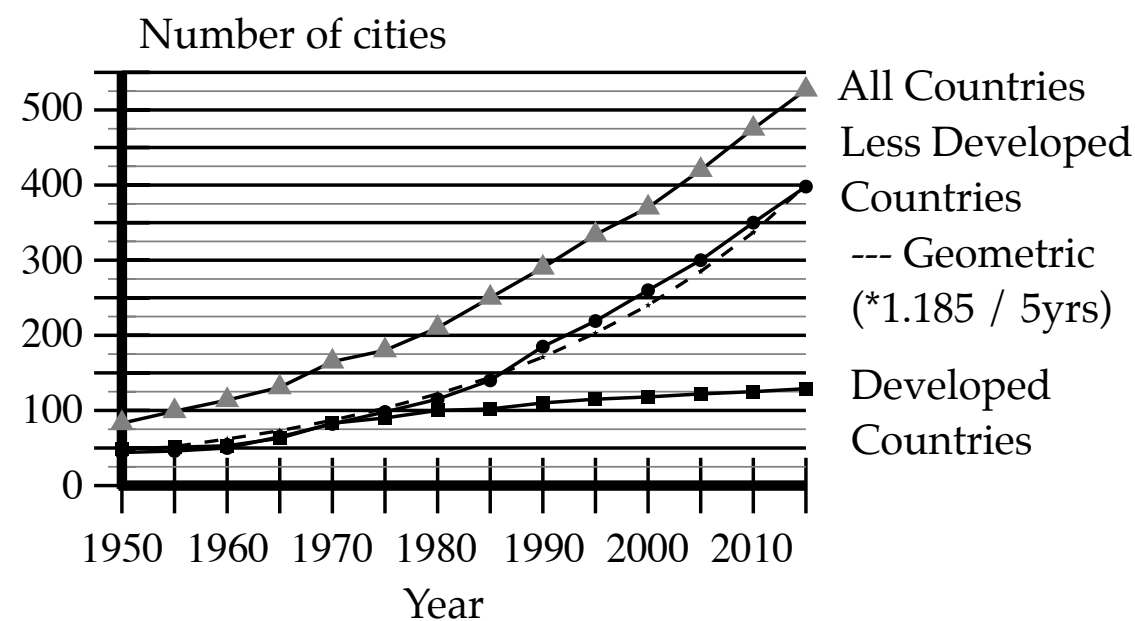

Figure 2. Source: U.N. 1997.

There have been major policy changes such as structural adjustment programs beginning in 1980 (Senegal) and 1983 (Tanzania), that may have significantly changed the situation migrants confront both in rural areas and in major urban cities throughout SSA. Yet studies of infant mortality (Lalou and LeGrand 1997) have long noted that it tends to be higher in rural areas than in urban ones and while scholars differ on their preferred explanations the education level of the mother seems at least to be a proxy for the causes. Studies of data from 1986 and 1981-5 from Senegal suggests that infant mortality rates continued to be higher in the rural areas relative to the urban ones (Brockerhoff 1990, Lalou and LeGrand 1997). While only comparative studies pre and post SAP could show whether SAPs have aggravated the situation it is probable that this is part of the post Bretton Woods causality that may help to explain the high levels of rural-urban migration. Some of the most interesting research questions, however, focus on the heterogeneity of risk exposure that different segments of the rural and urban population confront both across time and location. This, unfortunately, is not adequately captured in a few simple statistics.

The core of the dominant economic models focus tightly on easily quantifiable variables such as differentials in expected incomes and their implications, yet it has long been clear that empowerment issues are relevant as well (Sen 1981, 2000) and that the hazards of living in the urban environment need to be compared with the potential benefits of income in these areas (e.g. polluted water or insecure tenure with their associated costs versus greater variety of opportunities for socialization, income generation and household expenditures). From a business perspective, one area that has changed dramatically since the advent of SAPs is the relationship between the State and private enterprise (Thioub et al 1998, Boone 1992).

A minimal list of vulnerability issues (Blaikie et al 1994, Mitlin 1999, Moser 1996, Nomdo and Coetzee 2002, Satterthwaite 1999) discussed in the literature on sub-Saharan African cities, as well as most cities in developing countries, would include:

Environmental factors

- multiple risks (bacterial, heavy metal, and viral) as well as labor requirement linked to urban water supplies

- exposure to air born pollutants that are often orders magnitude higher than in the industrial world.

- endemic disease linked to crowded conditions including the presence of local disease vectors such as mosquitoes.

Socio-economic factors

- new migrants in particular lack social support systems and therefore have few resources 
Park, Greenberg, Nell, Marsh, Baro and Mjahed

to resolve a host of problems including household violence, adolescent socialization, and a variety of legal problems.

- the greater monetization of the urban economy imposes major problems on new migrants who may have serious problems making ends meet and can end up homeless in the streets.

- the major gap in income levels between segments of the urban population motivate risky behaviors on the part of the poor including theft, prostitution and for many young women the intensive search for a well off man (usually married) who will provide for them and possibly in the end marry them.

- changes in household structure and capital over time including consumer-worker ratios, human capital (health, skills, education), land, housing, and social capital (organizations, networks, extended families).

- changes in capital available to other groups such as homeless or individual migrants not embedded in a household.

Governance and global policy issues

- municipal governments of poor nations have almost insuperable problems extending urban services to rapidly burgeoning urban populations and new areas of major cities are poorly provided with all urban services including educational facilities, latrines and garbage collection.

- many poor residents make their living as street vendors (wamachinga in Dar es Salaam, in Dakar) and as urban traffic congestion grows so do the difficulties of getting to the areas selected for work.

- the high premium on housing including location, quality, size, and insecurity of tenure.

- the regulatory structures in municipalities is not conducive or even detrimental to capital accumulation by the poorer segments of society.

It is important to recognize that the very poor in the cities of SSA are regularly close to crisis and are thus particularly vulnerable to increased risks from any changes in their social or natural environment (Lupala 2002, Marsh and Oelofse 1998, Meshack, Luala and Sheuya forthcoming, Watts and Bohle 1993). Many segments of the urban population can sustain a moderate level of increased vulnerability due for example to an economic downturn, deterioration in urban services (Kanyama et al 2004, Kombe et al 2003) or even the failure of hospitals to have basic supplies but even minor changes can be catastrophic for some urban inhabitants. For decades the primary explanation offered for SSA's failure to develop has been "bad governance" and this has been most typically portrayed as a failure to manage the economy or provide services due to mismanagement rather than an inability to cope with population growth due to a simple lack of resources. Figure 2 above, suggests that the rapid urbanization of developing countries may have little to do with individual national policies, to the extent they are idiosyncratic, and that it is more probable that some global processes are at work. The recent UN report (UN Habitat 2003) now argues that the rapid growth of slums as major parts of the urban fabric in developing countries can be squarely placed on structural adjustment programs. Beyond slums there are the urban homeless who have in South Africa reached such numbers that they have formed the South African Homeless People's Federation for the urban poor (Bolnick 1999).

In the early 1980s, Tanzania and Senegal faced economic crises caused primarily by erosion in the terms of trade, rising foreign debt, shocks of rising oil prices, and severe droughts, among other factors. Their governments turned to the International Monetary Fund (IMF) and the World Bank (WB) and agreed to instituted Structural Adjustment Programs (SAP) (Messkoub 1996, IMF 1999 ) in return for loans. Following neoliberal perscriptions, SAP imposed the usual mixture of reform of government finance, cuts in government spending, devaluation, trade liberalization, and privatization. While these policies addressed inflation and the balance of payment deficits by restructuring the economy and changing the incentive structure to directly favor productive sectors, many argue that ordinary citizens and the poor have been made to pay the price (Beauchemin \& Odhiambo \& Manda 2003,Bocquier 2003, Gilbert 1994, ILO/JASPA 1992, Jamal \& Weeks 1988, Kanji 1996, Maxwell 1999, Potts 1997, Rogerson 1997, Simon 1997, Stren 1992, Tacoli 2002, UNCHS 1996).

Although there is abundant evidence that large segments of the population of these countries have been impoverished, there is some disagreement over whether or not this is a result of SAP. Some (Gellar 1995, Gervais 1993, Lewis 1987, Ndiaye 2001, Trager 1987, Weissman 1990). 
Morris (2001), for example, argues that impoverishment is a complex phenonoma driven by many internal and external factors besides SAP. While the literature on the social impact of adjustment has focused mostly on the immediate issues of health and nutritional status of vulnerable groups (Bell and Reich 1988, Cornia, Jolly, and Stewart 1987), others note that devaluations have driven up the costs of food, housing, and other commodities faster than real wages ( Aina 1993, Amis \& Lloyd 1990, Meeskoub 1996) and have pushed large segments of the population into the informal sector (Lewinson 1998, Lugalla 1995, Maliyamkono and Bagachwa 1990, Potts 1997, Rogerson 1997, Tripp 1990, 1997). The negative impact of the elimination of subsidies and the withdrawl of credit to small producers has been nearly universal, and many have abandoned the countryside apparently as a direct response to SAPs (Bryceson 1996, 2000, Faustin \& Takam 1992, Mokima, Mayoukou, and Dinga1992, Mtatifikolo 1992).

Under SAP, the infrastructure of most African cities has deteriorated. Urban services such as water supply, sewerage, electricity, public transport, and rubbish removal have been privatized or cost-recovery strategies instituted. The results have been fairly disasterous in Africa (Balisidya 1981, Gilbert 1992). "Services supplied to the rich gobble up most of the municipal budget" (Mattingly 1999:22). Without government subsidies, users are expected to pay the real costs of services. This has priced such services beyond the reach not just of the poor, but beyond the means of many (Bubba and Lamba 1991, Jones and Matrix 1995, Lee-Smith and Syagga 1989). Because of the debt crisis and foreign exchange shortages, maintaining existing infrastructure is difficult to say nothing of providing services to new areas of the city. As a result, planned sites are often so minimally serviced that they are nearly indistinguishable from unplanned ones (Stren and White, 1989). SAP effects on housing are no less dramatic. SAP policies have driven up the cost of housing and rents faster than income, making affordable housing (regardless of tenure) increasingly problematic for large segments of urban dwellers (Amis and Lloyd 1990, DurandLasserve 1994, Potts 1991 \& 1999, Rakodi 1992 \& 1995, Macoloo 1994). The introduction of cost-recovery systems in education and health has had an even greater impact on living standards (Bijlmakers et. al 1996, Chilowa and Roe 1990, Zaytoun 1991). The privatization of health care, for example, in Senegal has meant that some 60 percent of the population cannot afford regular health care ( Ndiaye 2001). Education presents a similar story. Not only are schools deteriorating, but the rising costs of schooling coupled with falling real wages are forcing children out of schools and into labor markets (Adepoju 1993, Kanji, 1993).

Against this backdrop it is important to remember that immigration of adults from rural areas to cities by itself provides adult skilled labor for which all the costs of socialization and education have been born by the rural area not the city and hence this implicit subsidy could be expected to differentially benefit the urban economy (Meillassoux 1972). It may be the case that the better educated and more skilled self select for immigration but this is not necessary for an explanation of the continuing attractiveness of cities to rural dwellers; earlier migration streams will elevate net urban standards of living above the rural norm until the state adequately prioritizes transfers to the rural area. A number of scholars have objected to studying globalization processes as entirely an impact model (or a form of dependency theory) in which developing economies try to evolve along preset economic paths in response to influences from without. One strand of thought, articulation theory, argued that dependency theory was far to simple (Portes 1978, Wolpe 1975). A later strand built on more radical revisions to Marxist theory and argued against what they viewed as the homogenizing ideas of economic theory (Bond 2000, Coronil 1997, Hart 2002, and Watts 1996). They proposed a less economistic alternative in which we might envisage urban spaces as representing a great variety of strategies with significant potential for generating original solutions to development questions and the developing world, more generally, as capable of doubt when it comes to developed world policy advice and agency when it comes to social, cultural and economic change.

Livelihoods address how people and households prioritize demands, and allocate available labor and assets. All households go through development cycles, changing their shape, size, assets, and livelihood strategies over time (Moser 1996). Consequently, households are diverse, as are their vulnerabilities and coping strategies (Table 2). Poverty and vulnerability are closely related, and the poor are usually the most vulnerable. The opposite of vulnerability is resilience (Nomdo and Coetzee 2002). Households respond to respond to economic fluctuations, periodic crises, and shocks. 
Park, Greenberg, Nell, Marsh, Baro and Mjahed

Table 2. Coping strategies of the poor

Intensification

Selling more labor

Migration

Informal sector

Urban agriculture

Taking in renters

\section{Management}

Borrowing

Exchange

Pooling

\section{Consumption}

Cutting

Delaying

Forgoing

\section{Selling Assets}

Luxeries

Replaceable

Strategic assets

Irreplaceable

Households reactions to SAPs involve transforming livelihood strategies into coping strategies (Baker 1995, Bigsten 1992, Boesen et al 1986, Holm 1992, Morris 2001, Moser 1998, Mustapha1991, Muthwa 1994, Narayan 1997, Rakodi 1994, 1995a \& 1995b). One such change is to work harder by either working longer hours, doing second jobs or activities, or putting additional members of the household into the labor market (Adepoju 1993, Bibangambah 1992, Bigsten and Kayizzi-Mugerwa, 1992, Jespersen 1990, Kanji 1993, Kulaba 1989, Maliyamkono and Bagachwa 1990, Roe and Chilowa 1990, Tripp 1989). Often this strategy entails efforts to diversify household income to spread risks and lessen vulnerablity (Bryceson 1999 \& 2002). Three common intensification strategies are migration, informal sector participation, and urban agriculture. Migration, has both internal and international dimensions, and remittances often are key components of household strategies (Barnes 1979, Caldwell 1969, Fall 1998, Faustin and Takam 1992, Gugler 1969, Mtatifikolo 1992, Oucho 1996, Rogerson 1995). The informal economy absorbs at least half of the workforce in many large African cities (Rondinelli and Kasarda, 1993:106), the influx of large numbers of migrants, and the rapid growth of cities has increased the competition even in this sector. As households intensify, there has been a tremendous expansion in participation by women in informal sector activities, particularly in activities that are an extension of domestic chores and traditional activities (e.g selling food, doing laundry, sewing, or brewing beer) (ILO-JASPA 1992, ILO 1994b, Kanji, N. and N. Jazdowska. 1993, Mwatha 1988, Rogerson 1991, Tevera 1993, Tripp 1989).

Another strategy employed by households to increase their incomes is to take in renters, which like other pooling strategies also can be a way to reduce costs. This strategy seems to be particularly significant for women (Andreasen 1987, Lee-Smith, 1990, Pennant 1990). The literature suggests that urban agriculture is another strategy of growing significance (DrakakisSmith1993, Freeman 1991,Gefu 1992, Lado1990,Maxwell 1995, Mlozi, Lupanga, and Mvena 1992, Rakodi 1985, Stern 1992, Tripp 1996). Urban agriculture seems to be part of a wider phenomena of agricultural activities by urban households often involving rural assets as well (Andrae1992, Bryceson 2001, Kamete 1998, Owuor 2004). Usually, these are part of multi-spatial livelihood strategies, involving complex economic and social relationships between family members and households in the city and countryside.

While remittances from urban migrants are well documented, the literature on rural-urban linkages also suggests that reverse flows, particularly of food, may play a crucial role in the food security of urban migrants (de la Briere et al 1997, Foeken and Owuor 2001, Kruger 1998, Potts 1995, O'Connor 1983, Smit 1998). Such strategies of intensification are not without costs. Where family members enter the work force, it is often at the expense of other vital activities such as child care or education (Friedman and Hambridge 1991, Gilbert 1994, Kanji 1995). Urban households that depend upon multi-spatial livelihood strategies not only may send remittances, have high transportation expenses, but may have high opportunity costs (as this strategy may preclude them from certain kinds of employment) (Fall 1998, Owuor 2004, von Troil 1992).

To make ends meet, households also employ a number of management strategies--borrowing, pooling of resources, labor exchanges etc., which depend upon social relations and social capital (Baker 1995 Drakakis-Smith 1992, 1993, Nelson 1987, 1997, Potts and Mutambirwa. 1990, O'connor 1983, Rakodi 1994,1995a, 1995b, Robertson 1984). Cutting consumption leads down the less desirable path of increasing vulernability ( Frankenberg and Goldstein 1992, Frankenberger and Lynham 1990, Maxwell and Frankenberger 1992). As households are forced into this alternative, expenditures on food, water, housing, education, health care are reduced. 
Research on Urbanization in the Developing World: New Directions

Expenditures are delayed, forgone, and not made. Things are not replaced (Care 1995, Chambers 1989, Chilowa and Roe 1990, Lindenberg 2002, Maxwell et al 1999, Morris 2001, Omari 1995). Among these the choice of where to live is often pivotal. Lower costs often translate into poorer access to services and higher risks, e.g. questionable tenure, greater enviromental and health risks, and increased transportation costs (Oelofse and Scott 2001). Belt-tightening and borrowing have limits, and once these limits are reached, the path toward ever increasing vulnerability leads to a downward spiral of selling off assets, first replaceable, but finally irreplaceable strategic assets (Frankenberger and Coyle 1993, Mougeot 1993).

\section{Potential of Methodology}

Future projects might build on this successful methodology developed with NSF funding between 1998 and 2002 and use 1 meter imagery and a multitude of already acquired urban images and data to study urban vulnerability in two cities (Dakar, Senegal and Dar es Salaam, Tanzania). The focus of such a project would no longer be methodological but scientific: it could use the methodology at an enhanced level to study the complex dynamics of changes in urban vulnerability for a gradient of urban inhabitants ranging from new immigrants in very precarious situations all the way to neighborhoods with better urban tenure, urban services and health outcomes. The new and already acquired remote sensing imagery and other urban data could be used to select 100 survey points in each city. At each point, it could study urban vulnerability issues, broadly conceived, through four focus groups (young / old by male / female). The full set of data from the focus groups could be used to create a household interview instrument and a random selection of six households at each point could then be interviewed. While urban surveys in the poorest areas of the world have been done, none provide a persuasive ability to explain the causes and consequences of the great variability in urban prospects found in the rapidly urbanizing areas of the developing world. New research could hope to develop persuasive models and to develop a cost effective way of doing urban research that would not be prohibitive for developing countries.

The end goal of such a project would be to construct persuasive models capable of explaining significant amounts of the variation in urban vulnerability. Both sampling points (using focus group data) and households (using household survey data) will be assessed in terms of vulnerability. We will begin by ranking areas of vulnerability in each focus group asking individual participants to prioritize risks. We will do the same in the household surveys but in each of these we will produce two rankings one for males and one for females. We will then use a ranked pairs method based on the ranking of binary pairs (Fishburn 1977) that was first detailed by Condorcet (1785) to resolve binary rankings into a ranked order of perceived risks for each sampling point as well as for each key constituency at each sampling point. These rankings can then be used as the dependent variable in a variety of analytical ways to test models we develop.

\section{Outline of a future proposal}

The general direction we would like to take in developing and applying the methodology will allow us to relate social and environmental variables to economic development factors. Although many NGO (Jones 1999) and World Bank studies (Booth et al 1999) of urban vulnerability have been done, showing a wide range of variability, they have not been very successful in actually understanding the causality behind this variability. Hypotheses abound: studies have pinned blame on SAPs, on poor governance, on lack of entrepreneurial spirit among othe factors. But we are more persuaded by the notion of development traps (Bencivenga and Smith 1997) which involve complex interactions between the environment, regulatory contexts, economic growth and change, SAPs and other policies, household strategies (we cannot assume everyone selects an optimal strategy), socialization infrastructure, health systems, and urban logistics (involving transport time and costs). This is a long list, but there is good evidence that under appropriate circumstances some or all of these may interact to create a 'development trap'. Our project will be to develop a framework to help understand this complexity. This framework will allow us to 
Park, Greenberg, Nell, Marsh, Baro and Mjahed

create models to study specific patterns of interaction between these various factors.

Following Nell (Nell 1998 and Nell et al, forthcoming) we will develop a set of 'transformational growth matrices' designed to display and analyze the changing relationships between the economic and the demographic, social, environmental and political sectors of society. In some cases - particularly when staying close to the economic factors - an input-output approach could be used, but in general, the effects are not easily captured in that format, because many of the most important effects are 'external', so specific amounts of inputs into well-defined processes cannot be identified. Instead, we will define a matrix that shows the 'cost impacts' of changes in these variables on each other at a moment of time. To put it more precisely, the impact is measured by how much of y must be transferred to or allocated to $\mathrm{x}$ to compensate for the action of $\mathrm{x}$ on $\mathrm{y}$. This procedure enables externalities to be incorporated; it doesn't matter whether the impact is direct or indirect. Estimating the 'impacts' will call for serious work developing indexes and proxies - but our previously developed methodology provides exactly the kind of techniques that will be needed.

The Matrix will show how changes in economic variables impact on demographic, social, household, environmental and, in some circumstances, political variables. And, of course, it will show the reciprocal impact of these other variables on those describing economic development. Several possibilities need to be examined: the secondary interactions could undermine or offset an initial positive development. In the first case, a positive development could be undermined by the interaction with the rest of the system, meaning that the initial effect could be reversed. For example, suppose that productivity increases, setting off economic growth, which then has negative environmental, health and demographic effects, so that these ultimately reverse the initial increase in productivity. A second possibility is that the sequence of interactions might leave the initial economic process intact - so that the growth initiated by the rise in productivity continues but the social, environmental and demographic processes might generate sufficient costs to offset the benefits from the positive economic. (Note that these negative possibilities are consistent with self-sustaining economic growth, whether market-driven, resulting from government planning, or supported by a mixed system. The economics may look all right, but be undercut by its external impacts.)

Of course, the desired pattern of interaction will be one in which the social, demographic, environmental and household reactions interact positively with the economic factors, and so support, rather than undermine, development.

The matrix will allow us to make a number of calculations that could be important in understanding and regulating economic development. One in particular concerns the important idea of 'sustainable development': A condition for sustainable development, derivable from the matrix, is:

$$
\begin{aligned}
& \text { Economic impact on social }+\quad=\quad \text { social }+ \text { environmental impact } \\
& \text { environmental variables } \quad=\text { on economic variables }
\end{aligned}
$$

The matrix sets out essential variables: economic relations, demographic change, socialization of adolescents, provision of social infrastructure, health and education, standard of living, the environment and political changes. It then shows how these impact on each other. Our household studies will enable us to supplement official data and data from other sources in order to do this. For example, we will be able to develop measures of the impact of pollution on household health, the impact of economic changes on the socialization of adolescents, the costs to households of the lack of social infrastructure, and so on. We would first fill in the matrix by drawing on our aggregate household data to determine whether the relationships appear to be positive or negative, and strong or weak. This will allow us to analyze the matrix for patterns of interaction, which will then indicate the key relationships that ought to be filled in numerically. These we will concentrate on.

Economic and demographic data can be obtained from official sources; official environmental data will be supplemented by our own studies. (We can also run some sample studies to check on the accuracy of official data, e.g. on incomes and household spending patterns.) Data on social infrastructure, health and education, and political institutions will all be available from official and other sources, but our surveys which will probe household histories 
Research on Urbanization in the Developing World: New Directions

will provide the means by which we can assess the impacts of changes in these variables on households and on each other. Once we begin to fill in the matrix we will have a tool with which to analyze interactions between these variables, and this will suggest further and more precise inquiries.

We do not suppose however that all segments of the city confront the same situation and we therefore expect that the same exercise using subsets of the data may illuminate key differences between urban classes and even genders. More generally, we imagine that different segments of the population pursue different strategies and in so doing confront different regulatory regimes as well as different financial and environmental risks. We will also use statistical analyses to study our ordinal rankings treating them as dependent variables and, building on our previous research we will further develop our agent based model to simulate an urban environment in which multiple strategies are reasonable

\section{Hypotheses}

A) Hypotheses behind our model construction.

$\mathbf{H}_{1}$ : Development policies leave imprints on the physical and social landscape that can be assessed through analysis of urban settlement according to date of construction.

$\mathbf{H}_{2}$ : Indices of vulnerability as well as rates of capital accumulation and standards of living will reflect complex interactions between changes in investments in socialization (education), health (delivery systems), infrastructure, environmental safety (housing construction, public health measures), and regulatory climate.

B)Hypotheses designed to investigate change in vulnerabilities over time and across periods of significant policy changes.

$\mathbf{H}_{4}$ : Urban food insecurity has been primarily a matter of distribution not outright shortages since the 1990s.

Discussion: The 1970s saw massive drought and famine that drove many Africans to the city, the better times since have disguised the problem of food insecurity even though prominent economists (Sen 2000) have noted that famine has regularly been a problem of distribution not shortfall.

$\mathbf{H}_{5}$ : Recent immigrants settle in areas where they have extended family and only a few then move to other areas of the city based on their perceptions of the advantages that locale offers.

Discussion: This may be quite false if immigrants migrate because they have particular skills they feel will be better rewarded in the urban area and then try to optimize their residential location to take advantage of those skills or if they rapidly select livelihood strategies and relocate to optimize their returns or if policy changes force changes in residence patterns.

$\mathbf{H}_{6}$ : As households age and children become adults young women used to primarily envisage early marriage but since the 1980s the expected age of marriage has increased among women in the most vulnerable segments of the urban population as independent earnings and the poverty of potential marriage partners have become critical.

Discussion: Since the 1980s attitudes toward sexuality and marriage have changed dramatically in African cities (Biaya 2001) and traditional early arranged marriages for women may no longer be the norm so it may even be the case that the vulnerable are more traditional than the wealthier classes.

C) Hypotheses relating to the role of government policies in alleviating or contributing to urban vulnerabilities.

$\mathbf{H}_{7}$ : Government codes regulating commerce have not empowered the poor and instead have acted to delegitimize many informal sector activities and inhibit capital accumulation by vulnerable groups such as women and new immigrants.

$\mathbf{H}_{8}$ : SAPs have restricted the capacity of the Dakar and Dar es Salaam municipalities to extend urban services to newly settled areas.

Discussion: Fiscal soundness at the national level has regularly been translated into tightening of funds for social services and this combined with rapid urbanization have left increasing numbers of immigrants to the urban area without basic services.

$\mathbf{H}_{9}$ : Insecure tenure, in squatter areas not subject to state sponsored programs providing the opportunity to establish tenure rights, inhibits capital accumulation by the poor but does not inhibit land speculation by those with capital. 
Park, Greenberg, Nell, Marsh, Baro and Mjahed

Discussion: Rent levels and housing construction respond to population growth but this primarily benefits those who have already accumulated capital unless municipalities are active in empowering new immigrants to acquire tenure rights.

D) Hypotheses relating to variability in vulnerabilities across time and space in the urban landscape.

$\mathbf{H}_{10}$ : The proportion of household budgets spent on food will be significantly higher in the more precarious areas of habitation and among new urban residents.

Discussion: The livelihoods available to new immigrants reflect more limited networks and skills than those of long term residents but older residents may also be near the edge and new immigrants may have ties to the rural area that sustain them.

$\mathbf{H}_{11}$ : Housing quality, location and date of construction are good, but not precise, predictors of variability in urban vulnerability including exposure to risk from disasters such as fire, flood and industrial accidents.

Discussion: Average levels of risk will be similar between precarious settlements of similar date but will still differ due to differences such as distance from environmental risks and proximity to economic resources to urban services. An alternative finding might be that older areas have deteriorated and only wealthier neighborhoods show lower levels of vulnerability.

$\mathbf{H}_{12}$ : Household sizes have increased in the new precarious settlements as economies of scale are forced on the poorest sectors of the population giving rise as well to increasing numbers of homeless.

Discussion: This is not obviously the case and some of our data from previous funded research suggests that household size forms part of a particular livelihood strategy.

$\mathbf{H}_{13}$ : Health expenditures on modern health treatments are increasingly rare among newer urban residents.

Discussion: Long term residents have had access to education and in the process have been somewhat alienated from traditional medical practice while recent inhabitants of the most precarious settlements are so close to financial failure that they cannot afford modern medical treatments.

E) Hypotheses about causes of the variability of coping strategies pursued by urban residents.

$\mathbf{H}_{14}$ : The prioritization of urban vulnerabilities will differ between the old and the young between men and women, as well as for other constituencies such as the homeless but they will also differ by date of arrival in the city and by location in the city.

Discussion: Too often studies fail to cover a representative sample of urban residents and assume that one simple set of priorities should dictate policy.

$\mathbf{H}_{15}$ : When households budgets are evaluated in terms of their degree of monetarization those that rely to a significant degree on direct consumption of resources obtained from own production or through reciprocity networks rather than purchase will be less vulnerable.

Discussion: We surmise that women may be particularly impacted by increases in monetization and forced to further prioritize market activities over unremunerated household activities.

$\mathbf{H}_{16}$ : Livelihood strategies of recent urban immigrants continue to include rural activities as well as urban ones.

Discussion: Increasing vulnerability pushes urban residents to both engage in urban agriculture and to rely on the rural area especially in certain seasons when the returns to labor there actually exceed those available to them in the urban area.

$\mathbf{H}_{17}$ : The location and frequency of meals is a good proxy for many other types of vulnerability.

Discussion: it is now common in African cities to have "air burgers" for lunch, i.e. swallow air for want of the means to eat anything at all. The number and frequency of traditional meals (sitting down with others) is declining for many urbanites.

F) Hypotheses relating to the capacity of remote sensing and GIS to further research into the causes of urban vulnerability.

$\mathbf{H}_{18}$ : Indices of distance to key economic resources (significant markets, superior employment possiblities) correlate with measures of vulnerability especially in new built areas.

Discussion: Distance in space will need to be complemented by distance in time and transportation costs but these may correlate fairly highly.

$\mathbf{H}_{19}$ : High resolution imagery (Quickbird) can be refined to derive quantitative measures of pollution sources such as garbage or flood prone areas across the urban landscape.

Discussion: The large levels of garbage and flood prone areas should in principle be detectable if 
the imagery is taken at the right time of the year but no one has yet attempted to detect garbage within African cities using Quickbird imagery and given the great variability in the size of deposits it is unclear how successful this attempt will be in accurately quantifying levels - though it will be easy to ground truth the attempt and perhaps with proper feedback significant successes will be achieved.

$\mathbf{H}_{20}$ : Diachronic imagery documenting change in urban vegetation, night time illumination, and urban habitation will significantly improve the sampling framework and allow smaller samples to pick up a greater proportion of the variability in urban vulnerability.

Discussion: This is a refinement of the hypothesis that we amply confirmed in prior NSF research except that that research was focused more generally on socio-economic variables and not specifically on urban vulnerability.

\section{Multidisciplinary Methodology}

\section{Mapping Infrastructure and Hazards}

To augment the already acquired medium-resolution SPOT satellite (20-m multispectral and 10-m panchromatic resolution) and Landsat Thematic Mapper (TM) (30-m multispectral) data available for each city we will acquire 4-6 SPOT images (1990s to present) and new highresolution Quickbird (http://www.digitalglobe.com) satellite imagery (0.6-m pixels panchromatic) for use in this project. Due to the high cost of Quickbird images ( $\$ 28$ per km sq) full coverage of the cities and their hinterland will not be feasible, but major portions of each city will be imaged. Prior knowledge of the cities from existing and new satellite imagery and geospatial data will be used to select appropriately representative portions for focused analysis. High-resolution imagery will serve three interconnected purposes: 1) to sharpen and improve the sampling framework, 2) to build institutional remote sensing capacity to be able to utilize this new data source, and 3) as a subject for applications research in image interpretation and feature extraction.

Working with small pixels $(\sim 1-\mathrm{m})$ presents new challenges and opportunities for image analysts more familiar with the previous generations of relative coarse spatial resolution (10-30 meter resolution) data. Notably, mixed-pixel effects are reduced so classification and feature aggregation are approached differently; visual interpretability of features is enhanced; bit depth and data volumes are significantly greater; and strategies for ground-based identification and accuracy assessment of features and classes are somewhat different because individual pixels cannot be accurately located in the field. Moreover, the processes of orthorectification and resolution merging (sharpening) of Quickbird imagery are different from those applied to other types of imagery, and can produce striking results that are intuitively interpretable and usable by non-specialists. This provides a powerful tool for public outreach and demonstration. Extending the institutional capacity within CSE and UCLAS (Baltsavias et al 2002, Mtalo 2002, Sliuzas, Gorte, Mtalo 2000, Hagai, Heinz, Mtalo 2002, Rubbhera et al 2001, Sliuzas et al 1999) to process and exploit high spatial resolution satellite imagery during the course of this project will have a direct impact on the long term sustainability of this work.

A primary application of the imagery will be informing and adding precision to the sampling framework. With a much higher resolution view of the urban landscape than is possible with Landsat or SPOT, the Quickbird data will provide details of buildings, neighborhoods, streetscapes and their contexts that will facilitate implementation of an area sample frame and the selection of survey households within it. In addition, detailed information about the physical setting of the households will be available for correlation with the results of the survey.

Precisely how much more information can be gleaned, and of what kinds, is another subject of research in this project. We hypothesize that informative features such as new housing, garbage accumulations, informal markets, garden plots, etc. may be visible. Their characteristics and locations can then be related to household surveys and other data. If the imagery could be acquired late in the wet season or just after it, low-lying areas of inundation may be visible and quantifiable, for analysis against disease risk, marginal housing or other factors. 
Park, Greenberg, Nell, Marsh, Baro and Mjahed

\section{Understanding Land-Use Change Over Time}

Urban sprawl will directly impact the environment of a city and the nearby natural resources. We propose to map urban areas with "City Light" satellite data and examine regional changes in the vegetation and natural resources with Earth observing satellites.

Nighttime images of the Earth acquired at visible wavelengths by the Defense Meteorological Satellite Program's Operational Linescan System (DMSP/OLS) provide a picture of urbanization through the detection of city lights as they are seen from space (Elvidge et al. 1997; Imhoff et al., 1997a). The stark contrast between lighted and unlighted lands provided by this type of image data makes it an evident choice for classifying and mapping land transformation to urban and suburban uses. The change in urban area over time could be used as a measure of the impact of urban land use on surrounding natural resources and productivity (Imhoff et al., 1997b). The DMSP group at the National Geophysical Data Center released a pair of DMSP-OLS "nighttime lights of the world" images processed specifically for the detection of change, covering the years 1992-93 and 2000. It is expected that this record can be extended to 2010 as new DMSP/OLS are scheduled to be launched when the lifetime of the current sensors expire.

Vegetation indices (VIs) derived from satellite data allow us to monitor seasonal, interannual, and long-term variations of vegetation parameters at the landscape scale. The Moderate Resolution Imaging Spectroradiometer (MODIS) VI products with their 250-m spatial resolution can be used to provide consistent, spatial, and temporal comparisons of global vegetation conditions that can be used to monitor vegetation growth or photosynthetic activity (Justice et al., 1998). The NDVI data (2000-present) are available free of charge and can be downloaded from the Land Processes Distributed Active Archive Center. The normalized difference vegetation index (NDVI) is produced globally over land at $250-\mathrm{m}$ resolution and 16-day compositing periods and will be used to detect vegetation changes by extracting the time-series data for the cities and their surrounding regions. An example of how these data can be used can be found on a website that provides geospatial tools and satellite data to landscape managers (http:/ /rangeview.arizona.edu/).

\section{Applications of remote sensing and GIS efforts}

Using this set of imagery we will classify the urban landscape with a focus on habitation and vulnerability: from a natural perspective (e.g. precarious housing in areas prone to inundation or near pollution sources such as garbage dumps). an infrastructural one (e.g areas with or without electricity or areas with substandard water sources) and a chronological perspective (e.g slums of recent origin, substandard housing that has been in the urban area for decades and others - we will use a variety of such classes). After classification, we will randomly select 100 points representing a broad range of vulnerability and these will become the focal point for further research.

In the final stages of the project we plan to incorporate the survey data and a variety of other data into a GIS which will be used as one component of our attempts to uncover causal relationships for the great variety of vulnerabilities within each city. Following the example of the MANDISA GIS in Cape Town (Nomdo 2002) we also plan to incorporate recent census data and data on disaster occurances (e.g. fire, flood, industrial accidents, epidemics) derived from government sources and newspaper archives.

\section{Social Science based Vulnerability Studies}

In the first year of the project the social science team will develop and collect data on urban disasters (from government and news media sources) and demographic features from the recent census in each country. In Year $2 \& 3$, the team will implement surveys at the 100 sample points which provide a spectrum of vulnerability from high to moderate that incorporates differences in infrastructure due to economic policies prevailing at each location at the time of settlement and subsequently. We will assess the vulnerability of local populations at each point using a variety of methods.

Initially a brief community meeting will assess the key constituencies (e.g. some areas may have many homeless others may not). This will then set up focus group discussions including 
Research on Urbanization in the Developing World: New Directions

minimally the four constituencies most likely to have significantly different experiences and concerns: dividing the population by gender and age (18-29 vs 30 or older). These discussions will be structured to include potable water and garbage issues, access to municipal and government services, tenure situation and problems, livelihood strategies with a focus on logistics and location of activities, education and socialization issues, and health with an emphasis on importance, location and type of health care services used.

Analysis of the results from the focus group discussions will then be used to develop a uniform household survey instrument so that six randomly selected households near each of the sampling points can be interviewed in greater depth about the issues raised in the focus groups as well as become the basis of more detailed historical information on residence, migration, history of capital accumulation, changes in vulnerability concerns over time, credit history, tenure and financial strategies and obstacles. Households will be drawn from a list of the closest 50 households using a stratified methodology to include all key constituencies. Part of this household survey will be to ask household women and men, separately, to reach a consensus ranking of a set of vulnerability concerns derived from the focus group discussions. We will also water samples from the potable water sources used by households at each sampling point. One product of both surveys will be a set of ranked priorities, based on the method of ranked pairs, reflecting perceptions of urban risk (see discussion above under Intellectual Merit and Innovativeness) from the separate perspectives of each focus group and of males and females in the household surveys.

\section{References}

Adepoju, A., ed. 1993. The Impact of Structural Adjustment on the Population of Africa: Implications for Education, Health and Employment. James Currey in association with United Nations Population Fund, London.

Aina, T. A. 1993. Development theory and Africa's lost decade: Critical reflections on Africa's crisis. In: M. von Troil, ea., Changing Paradigms in Development - South East and West: A Meeting of Minds in Africa. Scandinavian Institute of African Studies, Uppsala.

Amis, P. and P. Lloyd, eds. 1990. Housing Africa's Urban Poor. Manchester University Press, Manchester.

Andrae, G. 1992. Urban workers as Farmers: Agro-links of Nigerian textile workers in the crisis of the 1980s. IN J. Baker and P.O. Pedersen, eds., The Rural-Urban Interface in Africa: Expansion and Adaptation, Uppasla: Scandinavian Institute of African Studies, pp. 200-222.

Andreasen, J. 1987. Rented Rooms and Rural Relations: Housing in Thika, Kenya 1969-1985. Royal Danish Academy of Fine Arts, Copenhagen.

Baker, J. 1995. Survival and accumulation strategies at the rural-urban interface in northwest

Tanzania. Environment and Urbanization, vol. 7(1), pp. 117-132.

Balisisdya, Ndyanao. 1981. Shida [Troubles]. Dar es Salaam: University of Dar es Salaam Press.

Baltsavias, E. , T. Bouloucos, G. E. Mtalo, J. Niederost, U. Rivett (eds). 2002. Developments and Technology Transfer in Geomatics for Environmental and Resource Management - Proceedings of the Joint ISPRS Commission VI Workshop, 25th - 26th March 2002, UCLAS, Dar Es Salaam, Published by ISPRS Working Groups WGVI/1 \& WG VI/3

Barnes, S. T. 1979. Migration and land acquisition: The new landowners of Lagos. African Urban Studies 4: 59-70.

Beauchemin, C. \& P. Bocquier. 2003. Migration and Urbanization in Francophone West Africa: A review of the recent empirical evidence. Paris: DIAL, Document de Travail, DT/2003/09. 
Park, Greenberg, Nell, Marsh, Baro and Mjahed

Bell, D.E. \& M. R. Reich. 1988. Health, Nutrition, and Economic Crises: Approaches to Policy in the Third World, Mass: Auburn House.

Bencivenga, Valerie R. and Bruce D. Smith. Unemployment, Migration, and Growth. The Journal of Political Economy, Vol. 105, No. 3 (Jun., 199), 582-608.

Biaya, Tshikala Kayembe. 2001. Les plaisirs de la ville: masculinité, sexualité et feminité à Dakar (1997-2000). African Studies Review, Vol. 44, No. 2, Ways of Seeing: Beyond the New nativism (Sep.), 71-85.

Bibangambah, J. R. 1992. Macro-level constraints and the growth of the informal sector in Uganda. In: J. Baker and P. O. Pederson, eds., The Rural-Urban Interface in Africa: Expansion and Adaptation. Scandinavian Institute of African Studies, Uppsala, pp. 303-313.

Bigsten, A. 1992. Adaptation and distress in the urban economy: A study of Kampala households. World Development Vol. 20(10), pp. 1423-1441.

Bigsten, A. and S. Kayizzi-Mugerwa. 1992. Adaption and distress in the urban economy: A study of Kampala households. World Development 2(): 1423-1441.

Bijlmakers, L., M. Bassett, and D. Sanders. 1996. Heatlh and Structural Adjustment in Rural and Urban Zimbabwe, Nordiska Afrikainstitutet, Uppsala.

Blaikie, P. T. Cannon, I. Davis, and B. Wisner. 1994. At risk - Natural hazards, people's vulnerability and disasters. London: Routledge.

Boesen, J., K.J. Havenevik, J. Koponen, R. Odgaard. 1986. Tanzania: Crisis and Struggle for Survival, Uppsala: Scandinavian Institute of African Studies.

Bolnick, Joel. 1999. uTshani Buyakhuluma (The Grass speaks): People's Dialogue and the South African People's Federation. IN Jones and Nelson 1999:83-90.

Bond, P. 2000. Cities of Gold, Townships of Coal: Essays on South Africa's New Urban Crisis. Trenton, N.J., Africa World Press.

Boone, Catherine. 1992. Merchant Capital and the Roots of State Power in Senegal. Cambridge: Cambridge University Press.

Brockerhoff, Martin. 1990. Rural-to-Urban Migration and Child Survival in Senegal. Demography, Vol. 27, No. 4, November.

Bryceson, D. F. 1996. De-agriculturalisation and rural employment in sub-Saharan Africa: A sectorial prespective. World Development 20(10). 97-111. I

Bryceson, D. F. 1999. African rural labour, income diversification and livelihood approaches: A long-term development prespective. Review of African Political Economy, No 80, pp. 171-189.

*Bryceson, D. F. The scramble in Africa: Reorienting rural livelihoods. World Development 30(5):725-739.

Bryceson, D. 2001. Countryside and city: Balancing or blurring differences. IN J.D. Schmidt, et al. eds, Urban Development in a Transnational Context. Aalborg: Aalborg University Development Research Series, Occassional Paper 2.

Bryceson, D. 2002. Multipllex livelihoods in rural Africa: Recasting the terms and conditions of gainful employment. Journal of Modern African Studies, Vol.40(1),pp.1-28.

Bubba, N. and D. Lamba. 1991. Local Goverment in Kenya. Environment and Urbanization, vol 3(1). IIED, London.

Caldwell, J. 1969. African Rural-Urban Migration: The Movement to Ghana's Towns. C. Hurst, London.

CARE (1995), Rapid Food and Livelihood Security Assessment in Shinyanga, Mara and Mwanza Regions, CARE International in Tanzania, September 1995 
Research on Urbanization in the Developing World: New Directions

Chambers, R. 1989. Vulernability: How the poor cope. IDS Bullentin No 20(2).

Chilowa, W. and G. Roe. 1990. Expenditure patterns and nutritional status of low income urban households in Malawi. In: G. Roe, ea., Workshop on the Effects of the Structural Adjustment Programme in Malawi Volume 2: Papers Presented. Centre for Social Research, University of Malawi, Zomba.

Cornia, G.A., R. Jolly, and F. Stewart. 1987. Adjustment with Human Face: Protecting the Vulernable and Promoting Growth, Oxford: Oxford University Press.

Coronil, F. 1997. The Magical State: Nature, Money and Modernity in Venezuela. Chicago: Chicago University Press.

de la Briere, B. A. de Janvry, S. Lambert, and E. Sadoulet. 1997. Why do migrants remit? An analysis for the Dominican Sierra, FCND Discussion Paper no 37, IFPRI, Washington.

Drakakis-Smith, D. 1992. And the cupboard was bare: Food security and food policy for the urban poor. Geographical Journal of Zimbabwe 23: 38-58.

Drakakis-Smith, D. 1993. The Nature of Third World Cities. Working Paper 93.10, Centre for Development Research, Copenhagen.

Durand-Lasserve, A. 1994. Researching the relationship between economic liberalization and changes to land markets and land prices: The case of Conakry, Guinea, 1985-91. In: G. Jones and P. M. Ward, eds., Methodology for Land and Housing Market Analysis. UCL Press, London, pp. 55-69.

Datta, K. 1995. Strategies for urban survival? Women landlords in Gaborone, Botswana. Habitat International 19(1): 1-12.

Elvidge, C., K. E. Baugh, E. A. Kihn, and E. R. Davis. 1997. Mapping city lights with nighttime data from the DMSP Operational Linescan System. Photogrammetric Engineering and Remote Sensing 63:7 27-734.

Fall, A. S. 1998. Migrants' long distance relationships and social networks in Dakar. Environment and Urbanization Vol.10(1), pp. 135-146.

Faustin, M. and M. Takam. 1992. Interactions between development policies and population dynamics in a landlocked country: The Central African Republic. In: M. Touré and T. O. Fadayomi, eds., Migrations, Development and Urbanization Policies in Sub-Saharan Africa. CODESRIA, Dakar.

Fei, J.C.H. and G. Ranis. Development of the labor surplus economy. Homewood, 1964.

Feldman, David H. The Trade-off between GNP and Unemployment in a Dual Economy. Southern Economic Journal, Vol. 56, No. 1 (1989), 46-55.

Fields, Gary S. Public Policy and the Labor market in Developing Countries. in D. Newbery and N. Stern, eds., Modern Tax Theory for Developing Countries, World Bank, 1986.

Fields, Gary S. Rural-urban Migration, Urban Unemployment and Under-Employment, and JobSearch Activity in LDCs. 1975. Journal of Development Economics, June, 2, 165-87.

Fishburn, P. 1977. Condorcet Social Choice Functions, SIAM Journal of Applied

Mathematics, 33, 469-489.

Foeken. D. and S. O. Owuor 2001. Multi-spatial livelihoods in sub-Saharan Africa: Rural farming by urban households-- The Case of Nakuru, Town, Kenya. N M. de Bruijn, R. Van Dijk, and D. Foeken, eds., Mobile Africa: Changing Patterns of Movement in Africa and Beyond, African Studies Centre, Leiden: Brill, pp. 125-140

Frankenberger, T.R. and D. Goldstein. 1992. "The Long and the Short of It: Relationships Between Coping Strategies, Food Security, and Environmental Degradation in Africa" in Growing Our Future. K. Smith ed, New York, Kumarian Press. 
Park, Greenberg, Nell, Marsh, Baro and Mjahed

Frankenberger, T.R. and E. Coyle. 1993. Integrating Household Food Security into Farming Systems Research-Extension. Journal of Farming Systems Research Extension, Vol. 4, No. 1, p 35-66.

Frankenberger, T.R. and M.B. Lynham. 1990. Household Food Security and Coping Strategies Along the Senegal River Valley. In T.K. Park, ed. Risk and Tenure in Arid Lands: The Political Ecology of Development in the Senegal River Basin, UA Press, Tucson, Arizona.

Freeman, D. 1991. A City of Farmers: Informal Urban Agriculture in Open Spaces of Nairobi, Kenya. McGill University Press, Toronto.

Friedman, M. and M. Hambridge. 1991. The informal sector, gender and development. In: E. Preston-Whyte and C. Rogerson, eds., South Africa's Informal Economy. Oxford University Press, Cape Town, pp. 161-180.

Gefu, J. O. 1992. Part-time farming as an urban survival strategy: A Nigerian case study. In: J. Baker and P. O. Pederson, eds., The Rural-Urban Interface in Africa: Expansion and Adaptation. Scandinavian Institute of African Studies, Uppsala, pp. 295-302.

Geller, S. 1995. Senegal: An African Nation Between Islam and the West. Boulder: Westview Press.

Gerry, C. 1974. Petty producers and the urban economy : a case study of Dakar. Geneva, International Labour Off.

Gerry, C. 1977. Urban poverty, underdevelopment and 'recuperative' production in Dakar, Senegal. Swansea, Centre for Development Studies, University College of Swansea.

Gervais, R.R. 1993. Social dimensions of adjustment in Senegal: A failed opportunity? Labour, Capital and Society, 26(1), pp. 62-85.

Gilbert, A. 1992. Third world cities: Housing, infrastructure and servicing. Urban Studies 29: 435-460.

Gilbert, A. 1994. Third World cities: Proverty, employment, gender roles and the environment during a time of restructuring. Urban Studies 31: 605-633.

Greenberg, J. B. 1997a. Beyond the Polemic: Issues for a Political Ecology of Assessments of Structural Adjustment. Paper presented at Political Ecology Society/ Society for Applied Anthropology, Annual Meetings, Seattle, March 4-9.

Greenberg, J. B. 1997b. A Political Ecology Assessment of Structural Adjustment Policies: The Case of the Dominican Republic. Culture and Agriculture Vol. 19, No. 3: 85-93.

Greenberg, J. B. 1998. The Tragedy of Commoditization: The political ecology of the Colorado River delta's destruction. Research in Economic Anthropology, Vol. 19: 133-149

Greenberg, J. B. 2001. Globalization, Free Trade, and the Environment. An Ethnographic Exploration of the National Law Center for Interamerican Free Trade. Paper for the Political Ecology Society/Society for Applied Anthropology Annual Meeting, Merida, Mexico March 27April 1.

Gugler, J. 1969. On the theory of rural urban migration: The case of sub-Saharan Africa. In: J. A. Jackson, ea., Migration. Cambridge University Press, Cambridge.

Hagai, M., Heinz R., E. G. Mtalo. 2002. Application of snakes and dynamic programming optimisation technique in modelling of buildings in informal settlement areas, ISPRS journal of Photogrammetry \& Remote Sensing 56 (2002) 269 - 282

Harris, John R. and Michael P. Todaro. Migration, Unemployment and Development: A TwoSector Analysis. The American Economic Review, Vol. 60. No. 1 (1970), 126-142.

Hart, Gillian. 2002. Disabling Globalization. Places of Power in Post-Apartheid South Africa. Berkeley / Los Angeles: University of California Press. 
Research on Urbanization in the Developing World: New Directions

Heko. 1994. Wamachinga walipiza kisasi [Wamachinga get revenge]. Dar es Salaam, March 17:4. Holm, M. 1992. Survival strategies of migrants to Makambako - An intermediate town in Tanzania. In: J. Baker and P. O. Pedersen, eds., The Rural-Urban Interface in Africa: Expansion and Adaptation. Seminar Proceedings No. 27, Scandinavian Institute of African Studies, Uppsala.

ILO/JASPA. 1992. African employment report. Addis Ababa: International Labour Office.

ILO. 1994. Promoting Gender Equality in Employment in Lesotho: An Agenda for Action. Interdepartmental Project on Equality for Women in Employment, International Labour Office, Geneva.

IMF 1999. Senegal: Enhanced Structural Adjustment Facility Economic and Financial Policy Framework. Prepared by Government of Senegal in consultation with Staff of IMF and World Bank. International Monetary Fund.

Imhoff, M. L., W. T. Lawrence, D. C. Stutzer, and C. D. Elvidge. 1997a. A technique for using composite DMSP/OLS "city lights" satellite data to accurately map urban areas. Remote Sensing of Environment 61:361-370.

Imhoff, M. L., W. T. Lawrence, C. D. Elvidge, T. Paul, E. Levine, M. Prevalsky, and V. Brown. 1997b. Using nighttime DMSP/OLS images of city lights to estimate the impact of urban land use on soil resources in the U.S. Remote Sensing of Environment 59:105-117.

Jamal, V \& J. Weeks. 1988. Africa Misunderstood: Or Whatever Happened to the Rural -Urban Gap. International Labour Review, 127(3):271-292.

Jespersen, E. 1990. Household responses to the impact of the economic crisis on social services. In: G. Roe, ea., Workshop on the Effects of the Structural Adjustment Programme in Malawi Volume 2: Papers Presented. Centre for Social Research, University of Malawi, Zomba.

Jones, Sue and Matrix Consultants. 1995. Urban Poverty in Kenya, prepared for the British Development Division in Eastern Africa, Overseas Development Administration.

Jones, Sue and Nici Nelson. Urban Poverty in Africa from understanding to alleviation. London: Intermediate Technology Publications, 1999.

Justice, C.O., V. Salomonson, J. Privette, G. Riggs, A. Strahler, W. Lucht, R. Myneni, Y. Knjazihhin, S. Running, R. Nemani, E. Vermote, J. Townshend, R. Defries, D. Roy, Z. Wan, A. Huete, W. van Leeuwen, R. Wolfe, L. Giglio, J.-P. Muller, P. Lewis and M. Barnsley, The Moderate Resolution Imaging Spectroradiometer (MODIS): land remote sensing for global change research. IEEE Transactions on Geoscience and Remote Sensing 36 (1998), pp. 12281249.

Kanji, N. 1993. Gender and structural adjustment policies: A case study of Harare, Zimbabwe. Unpublished Ph.D. thesis, University of London.

Kanji, N. 1995. Gender, poverty and economic adjustment in Harare, Zimbabwe. Environment and Urbanization 7: 37-55.

Kanji, N. 1996. Review of Urbanization Issues Affecting Children and Women in Eastern and Southern African Region. New York: UNICEF.

Kanji, N. and N. Jazdowska. 1993. Structural adjustment and the implications for low-income urban women in Zimbabwe. Review of African Political Economy 56: 11-26.

Kamete, A. Y. 1998. Interlocking livelihoods: farm and small town in Zimbabwe. Environment and Urbanization, Vol. 7(1) pp. 37-56.

Kanyama A., Carlsson Kanyama A., Linden A., Lupala J.M. 2004. Public Transport in Dar es Salaam; Institutional Challenges and Opportunities for Sustaianble Transportation System, FOI, Stockholm. 
Park, Greenberg, Nell, Marsh, Baro and Mjahed

Kombe W., G.A. Kyessi, J. Lupala and E. Mgonja. 2003. Partnerships to Improve Access and Quality of Public Transport: A Case of Dar es Salaam, Tanzania, Water, Engineering and Development Centre (WEDC), Loughborough University, UK. ISBN 1843800373.

Kulaba, S. 1989. Local government and the management of urban services in Tanzania. In: R. E. Stren and R. R. White, eds., African Cities in Crisis: Managing Rapid Urban Growth. Westview Press, Boulder, Colo.

Kruger, F. (1998) Taking advantage of rural assets as a coping strategies for the urban. Environment and Urbanization, Vol 10(1), pp. 119-134.

Lado, C. 1990. Informal urban agriculture in Nairobi, Kenya. Land Use Policy 7: 257-266.

Lalou, Richard and Thomas K. LeGrand. 1997. Child Mortality in the Urban and Rural Sahel. Population: An English Selection, Vol. 9, 147-168.

Lee-Smith, D. and P. Syagga. 1986. Acces by the poor to Basic Infrastructure Services. Africa Regional Paper for the Economic Development Unit, Mazingira Institute, Nairobi.

Lee-Smith, D. 1990. Squatter landlords in Nairobi: A case study of Korogocho. In P. Amis and P. Lloyd, eds., Housing Africa's Urban Poor. Manchester University Press, Manchester, pp. 175-188.

Lesetedi, Gwen. 2003. Urban-rural linkages as an urban survival strategy among urban dwellers in Botswana: the case of Broadhurst residents. Journal of Political Ecology, Vol. 10:36-46.

Lewinson, 1998. Reading Modernity in Urban Space: Politics, Geography and the Informal Sector of Downtown Dar es Salaam, Tanzania. City and Space 10 (1) 205-222.

Lewis, J.P. 1987. Aid, Structural adjustment, and Senegalese agriculture. In Mark Gersovitz and John Waterbury, eds., The Political Economy of Risk and Choice in Senegal. London: Frank Cass \& Co. Ltd.

Lewis, W. Economic development with unlimited supplies of labor. The Manchester School of Economic and Social Studies, 22, 139-191, 1954.

Lindenberg, M. Measuring Household Livelihood Security at the Family and Community Level in the Developing World. World Development. 2002, Vol. 30, Issue 2, Pp. 301-318.

Lipton, Michael. Why Poor People Stay Poor: Urban Bias in World Development. London: Temple Smith, 1977.

Lugalla, Joe. 1995. Crisis, Urbanization, and Urban Poverty in Tanzania: A Study of Urban Poverty and Survival Politics. New York: University Press of America.

Lupala, John. 2002. Urban Types in Rapidly Urbanisaing Cities: Analysis of Formal and Informal Settlements in Tanzania, Built Environment Analysis, Royal Institute of Technology, (KTH), Stockholm, ISBN 91-7323-030-8.

Lupala, Aldo and John. 2003. The conflict between attempts to green arid cities and urban livelihoods: The case of Dodoma, Tanzania. Journal of Political Ecology, Vol. 10:25-35.

Lukas, Robert E. B. Migration Amongst the Batswana. Economic Journal, June 1985, 95, 358-82. Macoloo, C. 1994. Land price changes and residential development in Kenya: What future for the urban poor? Paper presented to the European Network for Housing Research 2nd Symposium, "Housing for the Urban Poor," Birmingham.

Maliyamkono, T.L. and M.S.D. Bagachwa. 1990. The Second Economy in Tanzania. London: James Currey.

Marsh, Stuart and Thomas K. Park. 2003. NSF Digital African Cities Project Sampling Procedures. Journal of Political Ecology, Vol. 10:57-67.

Marsh and Oelofse, C. 1998. Risk Assessment. Auslinks Environmental Training Manual for Development Facilitators. Cape Town: University of Cape Town. 
Research on Urbanization in the Developing World: New Directions

Mattingly, Michael. 1999. The Role of Government of Urban Areas in the Creation of Urban Poverty. IN Urban Poverty in Africa: From Understanding to Alleviation, S. Jones and N. Nelson, eds. London: Intermediate Technology Publicaitons, pp. 16-26.

Maxwell, D. 1999. The political economy of food security in sub-Saharan Africa. World Development 23(10): 1669-1681.

Maxwell, D., C. Ahiadeke, C. Levin, M. Armar-Klemesu, S. Zakariah, G. M. Lamptey. 1999. Alternative food security indicators: revisiting the frequency and severity of 'coping strategies.' Food Policy Vol. 24, pp. 411-429.

Maxwell, Simon, \& Timothy R. Frankenberger. 1992. Household food security: Concepts, indicators, measurements: A technical review. UNICEF and IFAD, New York and Rome.

Meillassoux, Claude. 1972. Maidens, Meal, \& Money. Cambridge University Press.

Meshack M., J.M. Lupala and S.A. Sheuya. Forthcoming. Conflicts in Community Managed Projects: The case of community-based projects in Dar es salaam and Zanzibar, Tanzania.

Messkoub, Mahmood. The Social Impact of Adjustment in Tanzania in the 1980s: Economic Crisis and Survival Strategies. Internet Journal of African Studies. No. 1, 1996.

Mitlin, Diana. 1999. Civil society and urban poverty. Theme Paper 5. Urban Governance. Partnership \& Poverty Series. Produced jointly by the International Development Department, School of Public Policy, University of Birmingham; International Institute for Environment \& Development, London: Department of City and Regional Planning, University of Wales, Cardiff; Department of Social Policy and Administration, London School of Economics.

Mjahed, M., G. L. Christopherson. 2003. "Using ArcInfo to Model Urban Development for Six African Cities." In Proceedings of 2003 ESRI International User Conference, San Diego, CA. Environmental Systems Research Institute, (http//:www.esri.com).

Mlozi, M. R. S., I. J. Lupanga, and Z. S. K. Mvena. 1992. Urban agriculture as a survival strategy in Tanzania. In: J.Baker and P. O. Pederson, eds., The Rural Urban Interface in Africa: Expansion and Adaptation. Scandinavian Institute of African Studies, Uppsala, pp. 284-294.

Mokima, J., C. Mayoukou, and M. N. Dinga. 1992. Effects of development policies in a sparsely populated country: The Congo. In: M. Touré and T. O. Fadayomi, eds., Migrations, Development and Urbanization Policies in Sub-Saharan Africa. CODESRIA, Dakar.

Morris, Mike 2001. Understanding Household Coping Strategies in Semi-Arid Tanzania. Department for International Development Strategy for Research on Renewable Natural Resources. National Resource Systems Programme. Final Technical Report. National Resource Institute, University of Greenwich. UK Deptarment for International Development.

Moser, Caroline O. 1996. Confronting Crisis - A comparative study of household responses to poverty and vulnerability in four poor households. Environmentally Sustainable Development Studies and Monograph Series No. 8. Washington, D.C. World Bank.

Moser, C. 1998. The asset vulnerability framework: reassessing urban poverty reduction strategies. World Development. Vol. 26(1),pp. 1-20.

Mougeot, L. 1993. Urban food self-reliance: Significance and prospects. IDRC Reports 21(3): 2-5. Mtalo, E. G. 1997. Fuzzy Sets Theory and Application in Engineering and the Surveying Sciences, Journal of Building and Land Development, Vol. 4, No. 3, pp.1 - 12.

Mtatifikolo, F. P. 1992. Population dynamics and soeioeconomie development in Tanzania. In: M. Touré and T. O. Fadayomi, eds., Migrations, Development and Urbanization Policies in SubSaharan Africa. CODESRIA, Dakar.

Mustapha, A. R. 1991. Structural Adjustment and Multiple Modes of Social Livelihood in Nigeria. Discussion Paper No. 26, United Nations Research Institute for Social Development, Geneva. 
Park, Greenberg, Nell, Marsh, Baro and Mjahed

Muthwa, S. W. 1994. Female household headship and household survival in Soweto. Journal of Gender Studies 3(2): 165-175.

Mwatha, R. G. 1988. Women business entrepreneurs in urban informal sector. Paper presented to the First International Conference on Urban Growth and Spatial Planning of Nairobi, Nairobi, Kenya.

Narayan, Deepa (1997), Voices of the Poor: Poverty and Social Capital in Tanzania, Environmentally and Socially Sustainable Development Studies and Monograph Series 20, World Bank, Washington DC.

Ndiaye, Abdourahmane . 2001. Foreign debt, structural adjustment programs and poverty in Senegal. Department of Economics and Management, Cheikh Anta Diop University, Senegal.

Ndoye, D. 1997. Le problème des biens immobiliers de la collectivité leboue de Dakar: questions historique, économique, sociale et juridique : les propiétés [sic] individuelles, les réserves des quartiers, les titres fonciers de la collectivité : les textes et la jurisprudence commentâes. [Dakar], Editions juridiques africaines.

Nell, Edward J. 1998. General Theory of Transformational Growth. Cambridge University Press. Nell, Edward J., Federico Mayor, and Jacques Attali. Forthcoming. Humanizing Globalization.

Nelson, N. 1987. Rural-urban child fostering in Kenya. In: J. Eades, ea., Migrants, Workers and the Social Order. Tavistock, London.

Nelson, N. 1997. How men and women got by and still get by, only not so well. IN J. Gugler, ed. Cities in the Developing World. Oxford: Oxford University Press.

Ndoye, D. 1997. Le problème des biens immobiliers de la collectivité leboue de Dakar: questions historique, économique, sociale et juridique : les propiétés [sic] individuelles, les réserves des quartiers, les titres fonciers de la collectivité : les textes et la jurisprudence commentâes. [Dakar], Editions juridiques africaines.

Nomdo, Christina and Erika Coetzee. Urban Vulnerability, Perspectives from southern Africa. Oxford: Periperi Publications, 2002.

Odhiambo, W. \& D. K. Manda. 2003. Urban poverty and labour force participation in Kenya. A paper presented at the "World Bank Urban Research Symposium", Washington, D.C., December 15-17, 2003.

O'Connor, A. 1983. The African City. Hutchinson, London.

Oelofse, G and D. Scott. 2001.Towards social and environmental justice in South African Cities: 'including invisible stakeholders' in environmental assessment procedures. South African International Association of Impact Assessment Conference, White River, 8-10 October.

Omari, C. K. 1995. Decision making and the Household: Case studies from Tanzania. IN C. Creighton and C.K. Omari, eds., Gender, Family, and Household in Tazania, Avebury, Aldershot.

Oucho, J. 1996. Urban migrants and rural development in Kenya. Nairobi: Nairobi University Press.

Owuor, Samuel O. 2004. Urban Households Ruralizing Their Livelihoods: The Changing Nature of Urban Rural Linkages in an East African Town. Paper presented at the African Studies Center Seminar Series, Leiden University, Netherlands.

Park, Thomas K. 2002. Mapping Urban Space and Place: The Six Cities Project. AAA annual meeting. New Orleans.

Park, Thomas K. 2003. Reflections on Resilience, Risk Management, and Flood Recession Agriculture. Social Dimensions of Hohokam Irrigation: Perspectives Across Cultures and Time. Workshop. Feb. 27-Mar.1, Tempe. 
Research on Urbanization in the Developing World: New Directions

Park, Thomas K. and Mamadou Baro. 2003. The Six Cities Project: developing a methodology of surveying densely populated areas using social science assisted and diachronic remote sensing based classification of habitation. Journal of Political Ecology Vol. 10:1-23.

Park, Thomas K., Mourad Mjahed and Luis Cisneros. Forthcoming. Modeling household dynamics in Marrakech, Bamako and Niamey: perspectives on robustness in urban environments. In Case Studies in the Robustness of Coupled Natural and Human Systems (edited by E. Jen, J.S. Lansing, T. Park, M.C. Stiner), Edited volume to be published jointly by the Santa Fe Institute and Oxford University Press.

Park, Thomas K. and Mourad Mjahed. 2003. Mapping household demographics in Marrakech, Bamako, and Niamey. SfAA annual meetings in Portland, Oregon.

Park, Thomas K. Condorcet, Marquis de. Forthcoming. Encyclopedia of Anthropology. H. James Birx, editor. Beverly Hills: Sage Publications.

Pennant, T. 1990. The growth of small-scale renting in low-income urban housing in Malawi. In: P. Amis and P. Lloyd, eds., Housing Africa's Urban Poor. Manchester University Press, Manchester, pp. 189-203.

Portes, A. 1978. Migration and underdevelopment. Politics Society 8(1):1-48.

Potts, D. 1995. Shall we go home? Increasing poverty in African Cities and migration processes. The Geographic Journal. Vol..161(3) 245-264.

Potts, D. 1997. Urban lives: Adopting new strategies and adapting rural links. In C. Rakodi, ed., The Urban Challenge in Africa: Growth and Management of the Large Cities, pp. 447-494. Tokyo/New York: United Nations Press.

Potts, D. 1999. The impact of Structural Adjustment on Welfare and Livelihoods: An Assessment by people in Harare, Zimbabwe. IN Urban Poverty in Africa: From Understanding to Alleviation, S. Jones and N. Nelson, eds. London: Intermediate Technology Publicaitons, pp. 36-59.

Potts, D. and C. C. Mutambirwa. 1990. Rural-urban linkages in contemporary Harare: Why migrants need their land. Journal of Southern African Studies 16(4): 676-698.

Potts, D. with C. C. Mutambirwa. 1991. Low-income housing in Harare: Overcrowding and commodification. Third World Planning Review 13(1): 1-26.

Rakodi, C. 1985. Self-reliance or survival?: Food production in African cities with particular reference to Zambia. African Urban Studies 21: 53-63.

Rakodi, C. 1992. Housing markets in third world cities: Research and policy into the 1990s. World Development 20(1): 39-55.

Rakodi, C. 1994 Urban poverty in Zimbabwe: Post-independence efforts, household strategies and the short-term impact of structural adjustment. Journal of International Development 6(5): 655-663.

Rakodi, C. 1995a. Poverty lines or household strategies? A review of conceptual issues in the study of urban poverty. Habitat International 19(4): 407-426.

Rakodi, C. 1995b. The household strategies of the urban poor: Coping with poverty and recession in Gweru, Zimbabwe. Habitat International 19(4): 447-472.

Rakodi, Carole. Urban governance, partnership and poverty: An overview of the research themes. Theme Paper 8. Urban Governance. Partnership \& Poverty Series. Produced jointly by the International Development Department, School of Public Policy, University of Birmingham; International Institute for Environment \& Development, London: Department of City and Regional Planning, University of Wales, Cardiff; Department of Social Policy and Administration, London School of Economics. 
Park, Greenberg, Nell, Marsh, Baro and Mjahed

Robertson, C. 1984. Sharing the Same Bowl: A socio-economic history of women and class in Accra, Ghana. Bloomington: University of Indiana Press.

Roe, G. and W. Chilowa 1990. A profile of low income urban households in Malawi: Results from a baseline survey. In: G. Roe, ea., Workshop on the Effects of the Structural Adjustment Programme in Malawi Volume 2: Papers Presented. Centre for Social Research, University of Malawi, Zomba.

Rogerson, C. M. 1991. Home-based enterprises of the urban poor: The case of spazas. In: E. Preston-Whyte and C. Rogerson, eds., South Africa's Informal Economy. Oxford University Press, Cape Town, pp. 336-344.

Rogerson, C. M. 1995. Forgotten places, abandoned places: Migration research issues in South Africa. In: J. Baker and T. A. Aina, eds., The Migration Experience in Africa. Nordiska Afrikainstitutet, Uppsala.

Rogerson, C. M. 1997. Globalization or informalization? African urban economies in the 1990s. In: C. Rokodi, ed., The Urban Challenge in Africa: Growth and Management of the Large Cities, pp. 337-370. Tokyo/New York: United Nations Press.

Rondinelli, D. A. and J. D. Kasarda. 1993. Privatization of urban services and infrastructure in developing countries: An assessment of experience. In: J. D. Kasarda and A. M. Parnell, eds., Third World Cities: Problems, Policies, Prospects. Sage, Newbury Park, Calif., pp. 134-160.

Rubhera R. A. M, C. Mato, A.M.G. Cramers, F.J.J.G. Janssen, J. H.Y. Katima, E. G. Mtalo. 2001. Coupling of GIS with the Drastic Model to Assess Groundwater Vulnerability to Pollution for the City of Dar Es Salaam, Tanzania In: Proceedings of 5th International Conference Diffuse/ Non-point Pollution and Watershed Management, Ed. C. S. Melching and Emre Alp, Milwaukee (WI), June 10-15.

Sardier, Marie. 2003. Women's Socio-Economic Roles in the Urban Sahel: A Preliminary Study of Bamako and Niamey. Journal of Political Ecology, Vol. 10:47-55.

Satterthwaite, D. 1999. The links between poverty and the environment in urban areas of Africa, Asia and latin America. International Institute for Environment and Development, Human Settlements Programme, United Kingdom.

Sen, Amartya. Development as Freedom. New York: Anchor Books, 2000.

Sen, Amartya. Poverty and Famines. An Essay on Entitlement and Deprivation. Oxford; Clarendon press, 1981.

Shaidi, Leonard P. 1987. Legal Control of Surplus Labor in Tanzania's Urban Centers. Workshop on Social Problems in Eastern Africa, Arusha.

Sliuzas, R. , B. Gorte, E. G. Mtalo. 2000. A Comparison of Visual Interpretation and two stage classification system for classifying Urban Development with SPOT XS, In: International Archives of Photogrammetry and Remote Sensing, Vol XXXIII, Amsterdam.

Sliuzas,R., M. Brussel, B. Gorte, R. Dekker, E. G. Mtalo (eds). 1999. Urbanisation in Dar Es Salaam: The Use of SPOT and ERS for Monitoring Urban Growth and Terrain Modelling, USP2 report 99-20, USP-2 project 3.1/AP-04, ISBN 905411290 5, Published by Belleids Commissie Remote Sensing (BCRS), Netherlands.

Simon, D. 1997. Urbanization, globalization and economic crisis in Africa. In: C. Rokodi, ed., The Urban Challenge in Africa: Growth and Management of the Large Cities, pp. 74-108. Tokyo/New York: United Nations Press.

Smit, W. 1998. The rural linkages of urban households in Durban, South Africa. Environment and Urbanization, Vol 10(1), pp. 77-87. 
Research on Urbanization in the Developing World: New Directions

Stifel, David C. and Erik Thorbecke. A dual-dual CGE model of an archetypal African economy: trade reform, migration and poverty. Journal of Policy Making. 25 (2003) 207-235.

Stren, R. 1992. African urban research since the late 1980s: Responses to poverty and urban growth. Urban Studies 29: 533-555.

Stren R. and R. R. White, eds., 1989. African Cities in Crisis: Managing Rapid Urban Growth. Boulder, CO: Westview.

Stiglitz, Joseph. The Efficiency Wage Hypothesis, surplus Labour and the Distribution of Income in LD.C.s. Oxford Economic Papers, July 1976, 28, 185-207.

Tacoli, C. 2001. Urbanization and migration in sub-Saharan Africa: Changing patterns and trends. IN N. M. de Bruijn, R. Van Dijk, and D. Foeken, eds., Mobile Africa: Changing Patterns of Movement in Africa and Beyond, African Studies Centre, Leiden: Brill

Tacoli, C. 2002. Changing rural-urban interactions in sub-Saharan Africa and their impact on livelihoods: A summary. London: Institute for Environment and Development (IIED), Working Paper 7, on Rural-Urban Interactions and Livelihood Strategies.

Tevera, D. S. 1993. Waste recycling as a livelihood in the informal sector: The case of Harare's Teviotdale dump scavengers. In: L. M. Zinyama, D. S. Tevera, and S. D. Cumming, eds., Harare: The Growth and Problems of the City. University of Zimbabwe, Harare, pp. 83-96.

Thioub, Ibrahima, Momar-Coumba Diop and Catherine Boone. 1998. Economic Liberalizatiion in Senegal: Shifting Politics of Indigenous Business Interests. African Studies Review, Vol. 41, No. 2 (Sep.): 63-89.

Thorbecke, E. A dual-dual framework to analyse the process of development. Paper prepared for a conference in memory of John C. H. Fei on The Economics and Political Economy of Development at the Turn of the Century, Taipei.

Tripp. A. M. 1996. Urban farming and changing rural-urban interactions in Tanzania. IN M.L. Swantz and A.M. Tripp, eds. What went right in Tanzania: People's Response to Directed Development, Dar Es Salaam: Dar Es Salaam University Press, pp. 98-116.

Troil, M. von. 1992. Looking for a better life in town: The case of Tanzania. In: J. Baker and P. O. Pedersen, eds., The Rural-Urban Interface in Africa: Expansion and Adaptation. Seminar Proceedings No. 27, Scandinavian Institute of African Studies, Uppsala.

Todaro, Michael P. A Model of Labor Migration and Urban Unemployment in Less Developed Countries. The American Economic Review, Vol. 59. No. 1 (1969), 138-148.

Trager, Lillian. 1987. A re-examination of the Urban Informal Sector in West Africa. Canadian Journal of African Studies 21:238-255.

Tripp, Ali Mari. 1997. Changing the rules: The Politics of Liberalization and the Urban Informal Economy in Tanzania. Berkeley/Los Angeles: University of California Press.

Tripp, Ali Mari. 1990. The Informal Economy, Labor and the State in Tanzania. Comparative Politics, vol.22(3), pp. 253-264.

Ulanowicz, Robert E. Ecology, the ascendent perspective. New York: Columbia University Press, 1997.

UNCHS. 1996. An urbanizing world: Global report on human settlements: London/Nairobi: Oxford University Press/United Nations Centre for Human Settlements (Habitat).

UN-Habitat. The Challenge of the Slums: Global Report on Human Settlements 2003. London, 2003.

United Nations. 1997. Department of Economic and Social Affairs. Population Division. http:/ /www.un.org/esa/population/pubsarchive/urb/urbcht2.htm. 
Park, Greenberg, Nell, Marsh, Baro and Mjahed

Van Vuuren, Anke (2000), Female-headed Households: Their Survival Strategies in Tanzania. ASC Working Paper 44, Afrika-Studiecentrum, Leiden.

Watts, Michael J. 1996. Development III: The global Agrofood System and Late 20th Century Development (or Kautsky Redux). Progress in Human Geography 20: 230-245.

Watts, Michael J. and H.G. Bohle. 1993. The space of vulnerability: The causal structure of hunger and famine. Progress in Human Geography, 17 (1), 43-67.

Weissman, S. R. 1990. Structural adjustment in Africa: Insights fromthe experiences of Ghana and Senegal. World Development, 18(12), pp. 1621-1635.

Werner, J.-F. 1993. Marges, sexe et drogues à Dakar : ethnographie urbaine. Paris, Karthala : Editions de l'ORSTOM.

Wikan, U. 1990. Changing housing strategies and patterns among the Cairo poor, 1950-1985. In: P. Amis and P. Lloyd, eds., Housing Africa's Urban Poor. Manchester University Press, Manchester, pp. 123-140.

Wolpe, H. 1975. The theory of internal colonialism. The South African case. Pp. 229-252, IN I. Oxaal, T Barnett and D. Booth eds. Beyond the Sociology of Development. London: Routledge \& Kegan Paul.

World Bank. 2001. African Poverty at the Millennium: Causes, Complexities and Challenges. Washington DC: World Bank.Zaytoun, M. 1991. Earnings and the cost of living: An analysis of recent developments in the Egyptian economy. In: H. Handoussa and G. Potter, eds., Employment and Structural Adjustment in Egypt in the 1990s. The American University in Cairo Press, Cairo. 